\title{
PEMANFAATAN INSTAGRAM OLEH KOMUNITAS WISATA GROBOGAN DALAM MEMPROMOSIKAN POTENSI PARIWISATA DAERAH
}

\author{
Wenday Dwi Novi Kurniawati \\ Program Studi Ilmu Komunikasi \\ Universitas Muhammadiyah Surakarta \\ Email : wendaydwik@gmail.com
}

\begin{abstract}
The existence of online community in the field of tourism through social media constructs the new form of developing and operating tourism sector. Social media is used for means of spreading information, communication and promotion. Promoting tourism potential can be carried out easily by these online community. one example of online community in the field of tourism is wisata grobogan community. the objective of this research is to describe the use of instagram done by wisata grobogan community in promoting potential of areas tourism. This research applies qualitative descriptive method. The object of the research is the account of @wisatagrobogan whis is used to promote the potential of areas tourism. Data is collected using semi-structured interview technique.Data analysis method used in this research uses triangulation. The results showed that in the promotion of the tourism potential of the area may go well and smoothly through the four stages, namely the presence of communicators, messaging, media and communicant. And the use of social media Instagram provides many benefits and advantages for Grobogan travel community in promoting the tourism potential of the area. Some of these benefits, among others, can easily disseminate travel information, and can attract the attention of other users more widely supported also by the use of features that are owned Instagram.
\end{abstract}

Keywords: photography,tourism communication, online community,social media, Instagram, promotion

\section{A. PENDAHULUAN}

Sebelumnya sudah banyak cara yang dipakai dalam memajukan pariwisata, misalnya menggunakan promosi di TV, iklan, brosur, dan pameran. Promosi pariwisata melalui media sosial bisa dikatakan sebagai cara yang tergolong baru dan berdampak besar juga dalam mendorong mobilitas wisatawan (Fatanti \& Suyadnya, 2015). Dengan menggunakan media sosial wisatawan atau konsumen dapat membagikan pengalaman mereka serta bisa juga digunakan sebagai sumber dalam pencarian informasi mengenai destinasi wisata (Gohil, 2015).Selain untuk promosi pariwisata, media sosial juga bisa menciptakan peluang bisnis. Facebook, Twitter, Instagram, merupakan beberapa contoh dari media sosial. Dimana penggunaannya harus terhubung dengan jaringan internet.
Media sosial penggunaannya dirasa mudah, hemat biaya dan efektif dalam pemasaran pariwisata bagi suatu daerah, maka hal tersebutyang membuat media sosial semakin diminati untuk sarana komunikasi dan promosi (Gohil, 2015). Selain itu penggunaan media sosial juga dapat dimanfaatkan untuk mengekspresikan pengalaman melalui foto maupun video bisa dalam bentuk komentar sebagai bentuk interaksi tidak hanya dengan keluarga tetapi juga bisa dengan orang lain. (Martínez, Berrozpe, \& Lasarte, 2014).

Banyaknya masyarakat yang mulai melakukan pemesanan daring dapat membuat industri pariwisata lebih makmur dan lebih efisisen dalam menjalankan bisnis maupun memajukan destinasi pariwisata mereka. Teknologi daring dapat dimanfaatkan sebagai sarana 
untuk berkomunikasi, menginformasikan, bernegosiasi, dan mengurangi kesenjangan komunikasi tanpa terhambat oleh jarak dan waktu yang dapat menciptakan struktur baru untuk pengembangan dan pengoperasian pariwisata (Hasan, 2015). Dari fenomena tersebut menunjukan bahwa memang cara tercepat dan yang dapat diandalkan bagi wisatawan untuk mencapai pendirian pariwisata adalah dengan melalui internet.

Penelitian yang telah dilakukan sebelumnya menunjukan manfaat dari penggunaan media sosial. Penelitian dari Fantanti dan Suyadnya (2015) menunjukan bagaimana Instagram membuat destinasi merek pariwisata di Indonesia khususnya di Bali dan Malang. Instagram berguna untuk mendorong promosi sebuah tempat menjadi tujuan wisata. Adanya fasilitas dalam Instagram seperti fotografi, geotagging, geolocation,hashtag, dan suka dapat mempermudah bagi pengguna atau wisatawan untuk mencari informasi tentang lokasi tujuan wisata. Semua fasilitas yang ditawarkan oleh Instagram memiliki potensi untuk mendukung dan menciptakan destination brand, terutama di bidang pariwisata. Pengguna berdasarkan media sosial atau User Generated Content (UGC) melalui media sosial dapat menciptakan minat terhadap produk dan tujuan. Seperti dalam penggunaan dikedua akun yang dimiliki oleh admin Bali dan admin Malang yang dijelaskan dengan melalui Instagramkeduanya memiliki potensi untuk melanjutkan, mengembangkan dan membuat gambar baru untuk tujuan pariwisata di Instagram.

Dengan adanya fenomena tersebut, membuka peluang besar bagi siapa saja dalam menggunakan Instagram untuk sarana berkomunikasi dan juga bisa digunakan sebagai sarana untuk mempromosikan potensi pariwisata. Biasanya potensi pariwisata masih minim diperhatikan pemerintah. Atas dasar itulah banyak bermunculan promosipromosi pariwisata yang dilakukan oleh satu atau dua orang, atau bahkan oleh komunitas. Komunitas yang dimaksud disini adalah komunitas yang berkomunikasi melalui media sosial yang biasa disebut sebagai komunitas virtual. Komunitas virtual merupakan suatu tempat berkumpulnya orang-orang yang ingin mencapai tujuan tertentu dalam mencari peluang baru serta ingin menjalin hubungan sosial dan ekonomi dengan orang lain (Wang, Yu, \& Fesenmaier, 2002).

Dalam penelitian ini peneliti tertarik dengan kegiatan komunitas wisata Grobogan pada akun Instagram @wisatagrobogan. Komunitas wisata Grobogan terbentuk dari gabungan beberapa pengguna Instagram yang mencoba mencari peluang dalam mendorong dan mengembangkan potensi pariwisata daerah yang belum dikelola dengan baik oleh pemerintah melalui akunnya @wisatagrobogan.

Dalam upaya mempromosikan potensi pariwisata, biasanya @wisatagrobogan menggunakan foto dan video sebagai bahan promosi pariwisata yang tujuannya dapat menarik calon wisatawan. Tetapi penggunaannya sebagian besar menggunakan foto dalam mempromosikan potensi pariwisata daerah. Apalagi Instagram menemukan bahwa penggunaan foto lebih diminati karena dirasa menarik dibanding dengan penggunaan check-in (measure). Menurut Goodman (dalam Martínez et al., 2014) menyatakan bahwa media sosial tersebut telah memberikan kontribusi untuk mengungkap pentingnya fotografi digital sebagai sarana ekspresi dan komunikasi, tidak hanya di kalangan teman-teman dan keluarga, tetapi juga pada orang asing. Dengan digunakannya foto yang diambil langsung dari tempat aslinya dalam suatu tempat pariwisata dapat menjadikannya daya tarik tersendiri bagi wisatawan.

Untuk itu peneliti memilih Instagram dikarenakan media tersebut juga banyak digemari untuk berbagi foto dan video. Serta penulis memilih akun @wisatagrobogan dikarenakan akun tersebut milik komunitas yang aktif dalam mempromosikan pariwisata daerah. Dalam upaya mempromosikan potensi pariwisata daerah, komunitas selalu tidak terlepas dari penggunaan media sosial Instagram serta dalam upaya mempromosikan potensi pariwisata daerah ini @wisatagrobogan melakukannya secara 
sukarelatanpaadanyaikutcampurdanbantuan dari dinas. Hal tersebutlah yang mendorong dan menarik untuk diteliti oleh peneliti. Maka dilakukannya penelitian ini bertujuan untuk mengetahui komunikasi pariwisata yang dilakukan oleh komunitas wisata Grobogan serta untuk dapat mengetahui bagaimana pemanfaatan Instagram oleh komunitas wisata Grobogan yang digunakan sebagai sarana mempromosikan potensi pariwisata daerah khususnya di daerah Grobogan.

\section{B. TELAAH PUSTAKA}

\section{Komunikasi Pariwisata Dalam Media Sosial Berbasis Fotografi}

Menurut Urry (dalam Liu, 2016) fotografi menggambarkan bagaimana wisatawan membagikan pengalaman wisatamereka dan menggambarkan terjalinnya hubungan antara pengalaman wisata dengan fotografi wisata. Adanya fotografi yang dilakukan bukan hanya memungkinkan mereka berbagi pengalaman wisata tetapi juga bisa menghasilkan dampak yang dramatis pada orang lain. Dimana menurut Tussyadiah dan Fesenmaier (dalamLiu, 2016) menyatakan bahwa hal tersebut juga dapat berfungsi sebagai sumber informasi wisata bagi wisatawan lain yang ingin merencanakan perjalanan wisata mereka.

Penggunaan gambar atau foto dijadikan hal yang menarik dalam komunikasi pariwisata.Gambar merupakan salah satu dasar yang mendukung baik pada tingkat konsumsi maupun pada tingkat produksi. Fotografi dan media sosial menjadi teknologi mediator dalam penciptaan dan difusi citra tujuan wisata. Akehurst (dalam Martínez et al., 2014), penggunaan gambar pada media sosial kini menjadi salah satu alat promosi tertinggi dalam bidang pariwisata. $\mathrm{Hal}$ tersebut diakibatkan karena menurut McQuail (dalam Liu, 2016), pengguna tanpa sadar dipengaruhi oleh media yang mereka gunakan.Sehingga keputusan wisatawan dalam merencanakan perjalanan dapat diubah dengan menggunakan situs umum yaitu dengan media sosial.

Salah satu contoh media sosial yang mempunyai layanan berbagi foto adalah Instagram. Instagram merupakan aplikasi yang juga menyediakan fitur seperti update status, check-in, retweet, seperti pesan langsung, dan merekomendasikan bagi pengguna untuk memperbarui informasi. Instagram awalnya hanya digunakan sebagai sarana untuk fotografi secara daring, sekarang berubah sebagi penyedia informasi yang cepat, tepat dan akurat serta sebagai sarana untuk berpromosi, pemasaran, distribusi baik untuk barang ataupun jasa (Hoffman \& Novak; Doolin et.al; \& Sweeney dalam Fatanti \& Suyadnya, 2015).

Stepchenkova dan Zhan ( dalam Fatanti \& Suyadnya, 2015), menyatakan mengambil foto berarti media "menangkap" realitas. Hal tersebut dapat menggambarkan ketika fenomena capture wisata dilakukan melalui kamera ponsel mereka berarti mereka mencoba untuk mengirim kenyataan sebagai pesan untuk dirinya sendiri maupun untuk orang lain terhadap pengalamannya sebagai wisatawan. Telah banyak fenomena yang muncul dimana wisatawan lebih percaya pada gambar/foto dan opini wisatawan lain dibandingkan dalam perusahaan wisata yang sudah menyediakan informasi. Dalam konteks pariwisata, fotografi secara daring menciptakan persepsi yang positif dari wisatawan mengenai tujuan wisata.

Didalam penggunaan Instagramterdapat beberapa kemungkinan yang dapat mempermudah kita, seperti:1) Instamazing, yang memungkinkan kita mencari geolocations untuk melihat letak foto-foto terbaru, memungkinkan mencari pengguna dan hashtag yang memberikan hasil kata pencarian baik untuk semua orang yang termasuk kata itu serta sejumlah foto dengan masing-masing hashtag, 2) Findergram, memungkinkan pencarian hashtag, memberikan pilihan untuk menampilkan gambar yang sedang diunggah mereka, hasil pencarian terbatas karena hanya menunjukan jumlah foto-fotoyang dikelompokan, 3) WorldCam, untuk search engine foto geolocated tidak hanya di kota tetapi di tempat-tempat tertentu di berbagai kota, 4)Webstagram, memungkinkan mencari 
hashtag dan kata kunci yaitu dengan menemukan foto dimana kata itu muncul dalam beberapa cara atau yang lain, baik sebagai hashtag (memberikan jumlah total foto) atau hanya sebagian dari nama pengguna dari judul foto, 5)Search Stagram, dengan mesin pencari dengan kata kunci dan hashtag dimana ia dapat menyarankan hashtag terkait, 6) Nitrogram, situs yang fokus pada menawarkan pengguna Instagram kemungkinan menjaga kontrol dari aktivitas mereka dan interaksi dengan pengguna lain. Menghasilkan statistik berdasarkan jumlah foto diunggah, pada suka dan jumlah komentar yang diterima (Martínez et al., 2014).

Instagram telah unggul sebagai alat komunikasi dan alat pemasaran yang efektif untuk menampilkan produk dengan deskripsi visual. Dilihat dari data penggunaan layanan statistik, terdapat 200 juta pengguna terdaftar, foto yang telah diposting sejumlah 20 miliar, dan perharinya rata-rata foto yang diunggah berjumlah 60 juta. Dari hasil tersebut Instagram dianggap menjadi media sosial yang paling populer untuk berbagi foto dan juga dapat digunakan untuk berinteraksi dengan teman,orang lain maupun brand di seluruh dunia(Ara et al., 2014).

Oleh karena itu, peran teknologi informasi dalam sarana distribusi, promosi dan koordinasi sangat penting. Penggunaan media sosial telah tumbuh menjadi salah satu cara yang paling efektif bagi wisatawan untuk mencari informasi dan berbagi pengalaman bepergian (Cox et al;. Gretzel; Yoo \& Gretzel dalam Gohil, 2015).

\section{Komunikasi Pariwisata Oleh Komunitas Daring}

Pariwisata merupakan suatu yang berkaitan dengan adanya orang asing yang tinggal di suatu tempat tapi tidak untuk menetap hanya untuk tujuan rekreasi, pengembangan pribadi dan mempelajari keunikan suatu wisata (Oktavia, 2015). Sedangkan dasar dari kegiatan promosi ataupun pemasaran adalah komunikasi. Komunikasi dimaksudkan terjadinya interaksi berupa pertukaran informasi. Dalam konteks pariwisata informasi tentang sebuah destinasi atau tentang even sebagai penawaran destinasi akan mempengaruhi permintaan pariwisata. Adanya perpindahan tempat saat melakukan perjalanan wisata memungkinkan di tempat pariwisata tersebut pasti akan terjadi komunikasi antara pihak penduduk setempat dengan pihak pendatang atau wisatawan yang datang berkunjung ke tempat tersebut.

Komunikasi dalam pemasaran produk pariwisata biasanya dapat dilakukan secara tatap muka, dengan cara komunikasi antar pribadi dan dengan cara bermedia, seperti yang dilakukan melalui media sosial dalam Instagram misalnya. Biasanya komunikasi pariwisata melalui media sosial yang diarahkan pada tujuan promosi pariwisata bersifat membujuk wisatawan (Oktavia, 2015). Paran media sosial sendiri sangat diperlukan untuk melakukan komunikasi kepada calon pembeli agar permintaannya dapat tercapai (Utama, 2014).

Melalui media sosial, orang dapat berbagi gambar, komentar dll yang bisa digunakan untuk berbagi dengan keluarga, teman dan bahkan bisa juga dengan orang asing (Martínez et al., 2014). Melalui media sosial pengguna lain juga bisa mengomentari publikasi, berbagi, memberi tag, menyebarkan gambar dan komentar mereka sendiri. Menurut Buhalis (dalam Bash, 2015), dengan adanya perkembangan teknologi internet menjadikan media sosial sebagai sarana baru yang dimanfaatkan oleh organisasi dan wisatawan dalam mencari tujuan wisata. Facebook, youtube, twitter, dan Instagram merupakan beberapa contoh dari media sosial dan bisa juga dikenal sebagai Web 2.0.

Tantangan dalam bisnis pariwisata adalah tuntutan penyediaan berbagai kegiatan dan fasilitas yang dapat memenuhi kebutuhan atau kegiatan wisatawan, memelihara dan mengendalikan mutu layanan. Menurut (Oktavia, 2015), komunikasi dalam kegiatan promosi produk pariwisata di bagi menjadi tiga bagian penting, yaitu:

1. Harus ada komunikator yang bertanggung jawab terhadap pemasaran produk yang dihasilkan 
industri pariwisata di daerahnya. Mereka merumuskan berita (messages) yang akan disampaikan pada calon konsumen (receive)

2. Harus ada receiver yang akan menerima berita dari komunikator

3. Harus ada alat untuk menyampaikan messege berupa chanel yang bertindak sebagai media saluran berita.

Dilihat darifenomena sekarang ini, banyak wisatawan yang menggunakan media sosial berbasis internet untuk berkomunikasi dalam upaya mencari tahu informasi mengenai pariwisata dan juga digunakan sebagi acuan mereka dalam bepergian. Menurut (Fatanti \& Suyadnya, 2015), adanya media sosial juga memberikan kesempatan bagi pengguna untuk berpartisipasi, mengembangkan dan memperbarui informasi apapun. Hal tersebutlah yang memicu terbentuknya komunitas daring.

Komunitas daring/ virtual merupakan komunitas yang media dalam komununikasinya dilakukan melalui internet yang cakupannya lebih luas dibanding komunitas offline. Menurut para ahli sosiologi, sebuah komunitas memiliki empat ciri utama, yaitu; adanya keanggotaan di dalamnya, adanya saling mempengaruhi antara anggota satu dengan yang lainnya, adanya integrasi dan pemenuhan kebutuhan antar anggota dan adanya ikatan emosional. Jadi komunitas adalah adanya kelompok orang yang memiliki identitas yang hampir sama dimana faktor lokasi tidak menjadi penghalang (Komputindo, 2008).

Komunitas daring berperan dalam memberikan informasi serta memfasilitasi promosi pariwisata tehadap wisatawan(Hasan, 2015). Untuk itu, banyak wisatawan yang beralih ke komunitas perjalanan daring untuk memenuhi kegiatan yang berhubungan dengan perjalanan mereka, mulai dari mencari informasi wisata dan tips, membuat transaksi wisata, membina hubungan dengan orang-orang dari jauh, menemukan teman perjalanan, atau hanya bermain game untuk tujuan hiburan.

Hadirnya komunitas daring yang bergerak dalam industri pariwisata juga menciptakan peluang bisnis (baru). Komunitas daring ini terbentuk dari komunitas lokal yang berupaya dalam perencanaan pengembangan potensi pariwisata melalui media sosial. Melalui media sosial tersebut mampu digunakan untuk melakukan gerakan perubahan. Dijelaskan oleh Astuti dalam (Ardella, 2015), bahwa para pengguna media sosial ini bisa disebut sebagai produsen sekaligus sebagai konsumen dalam kegiatan saling bertukar informasi.

Dibandingkan dengan media cetak, media sosial dipilih sebagai sarana komunikasi dan promosi yang paling banyak diminati karena penggunaannya dirasa mudah, hemat biaya, dan efektif dalam pemasaran pariwisata bagi suatu daerah (Gohil, 2015). Pemanfaatan teknologi oleh komunitas daring mempermudah dan mempercepat jangkauan komunikasi dengan relasi ke komunitas industri maupun wisatawan, baik one to one, one to many, maupun many to many, serta dapat membantu pelanggan dengan baik dalam mempertahankan relasi juga memfasilitasi adanya pertukaran informasi, ide produk, dan pelayanan untuk memenuhi kebutuhan dan keinginan pasar (Hasan, 2015).

Adanya penyediaan informasi mengenai pariwisata menjadikan komunitas daringini semakin diminati oleh wisatawan. Menurut (Hasan, 2015), Adanya Komunitas daringmenggunakan media sosial sebagai sarana komunikasi dalam hal pariwisata disebabkan karena media sosial mempunyai tiga power atau kelebihan dalam pemasaran:

1. Media sosial tidak komersial

Memungkinkan orang lebih mudah untuk berhubungan dengan teman dan keluarga mereka, untuk membuat hubungan dengan orang lain dengan minat yang sama, dan untuk mendukung kegiatan sosial yang dilakukan komunitas daring.

2. Media sosial dapat melakukan yang terbaik

Dapat dijadikan sebagai media untuk kampanye yang paling populer dan 
sukses dalam pemasaran melalui gerakan sosial (social marketing), yang dirancang agar masyarakat berkeinginan untuk berbuat baik serta untuk terlibat dalam membentu orang lain

3. Merek yang kuat memiliki kelebihan dalam media sosial

Destinasi, resort, dan atraksi yang mempunyai posisi merek yang jelas cenderung akan bisa mengungguli merek lain dalam media sosial.

Dalam bidang wisata, komunikasi yang dilakukan oleh komunitas daring menunjukan respon positif dalam mempengaruhi wisatawan baru dimana model tersebut menekankan efektivitas komunikasi bukan efisiensi (Hasan, 2015).Pengembagan warisan budaya lokal tergantung inisiatif masyarakat setempat yang membentuk suatu komunitas daring.

Suatu daerah biasanya mempunyai potensi akan pariwisatanya. Apalagi dalam bidang ekonomi pariwisata mempunyai banyak manfaat seperti: dapat mendatangkan devisa bagi negara yang diperoleh dari wisatawan mancanegara, memperluas lapangan kerja masyarakat, meningkatkan pendapatan masyarakat terutama yang tinggal disekitar objek wisata,meningkatkan pendapatan asli daerah (PAD), antara lain pendapatan yang berasal dari biaya karcis masuk, biaya parkir kendaraan dan yang lainnya (Karyati, Mulyani, Rachmat, Junarti, \& Sunarto, 2007).

Adanya komunitas daring yang bergerak dalam bidang pariwisata telah semakin diakui sebagai sumber informasi penting bagi para konsumen dan sebagai saluran pemasaran/ promosi yang efektif bagi pemasar (Sciences, 2008). Melihat fenomena tersebut dimana wisatawan beralih menggunakan media daringdalam pemenuhan kebutuhan, untuk itu Kozinets (dalam Ballantine \& Ballantine, 2016) menyatakan bahwa semakin lama pengguna internet melakukan kegiatan daring, semakin besar kemungkinan untuk tertarik pada kelompokdaringatau sejenisnya. Sekali konsumen berinteraksi dengan orang lain secara daring, diasumsikan bahwa mereka bisa jadi akan menjadi anggota berulang dari satu atau lebih dari komunitas ini, dan dari waktu ke waktu akan beralih menjadikan komunitas daring ini sumber informasi dan interaksi sosial.

\section{METODE}

Metode yang digunakan dalam penelitaian ini adalah deskriptif kualitatif. Alasan peneliti menggunakan metode tersebut dikarenakan peneliti berusaha untuk mendiskripsikan dan memperoleh informasiinformasi mengenai fenomena atau peristiwa secara sistematis secara apa adanya. Seperti pada fenomena pemanfaatan sosial media Instagram oleh komunitas yang dijadikan sebagai sarana dalam memromosikan potensi daerah. Menurut Mardalis (2006) dalam melakukan penelitian maka peneliti dituntut untuk mengetahui dan menerapkan prinsipprinsip seperti penelitian perlu dirancang dan diarahkan guna memecahkan sesuatu masalah tertentu, penelitian tekanannya untuk mengembangkan generalisasi, prinsip-prinsip, serta teori-teori, berangka dan bermula pada masalah atau objek yang diteliti serta penelitian memerlukan observasi dan deskripsi yang akurat. Dengan kata lain penelitian deskriptif bertujuan untuk memperoleh informasi-informasi mengenai keadaan saat ini dan melihat kaitan antara variabel-variabel yang ada.

Objek dalam penelitian ini adalah akun Instagram @wisatagrobogan. Untuk meneliti objek penelitian tersebut, maka penting bagi peneliti untuk melakukan wawancara kepada admin dari akun @wisatagrobogan sebagai pihak yang bertanggung jawab dalam menjalankan akun tersebut serta wawancara kepada pendiri komunitas, fotografer dan anggotayang berperan aktif dalam komunitas. Serta tidak kalah penting juga melakukan observasi pada akun @wisatagrobogan itu sendiri.

Wawancara yang dilakukan peneliti dalam penelitian ini adalah wawancara mendalam dan wawancara semi terstruktur, dengan cara melakukan tanya jawab mengenai satu topik yang telah ditentukan 
untuk memperoleh hasil yang diinginkan peneliti, serta penggunaan wawancara semi terstruktur menurut (Herdiansyah, 2013), tepat digunakan dalam penelitian kualitatif karena peneliti diberi kebebasan sebebasbebasnya dalam bertanya dan memiliki kebebasan dalam mengatur alur dan setting wawancara. Sedangkan observasi yang dilakukan oleh peneliti terhadap akun Instagram @wisatagrobogan dari postingan periode bulan Oktober 2015 hingga Mei 2016. Peneliti melakukan observasi pada bulan-bulan tersebut dikarenakan pada bulan-bulan tersebut terlihat dalam akun @ wisatagrobogan banyak melakukan promosi melalui kegiatan yang diadakan oleh komunitas wisata Grobogan, baik kegiatan yang dilakukan secara online maupun offline yang bertujuan bukan hanya untuk meningkatkan dan mendorong eksistensiakun @wisatagrobogan dalam mempromosikan pariwisata daerah tetapi juga untuk menarik para pengguna Instagram lain agar mau berpartisipasi ikut serta dalam kegiatan yang diadakan oleh komunitas. Dalam penelitian ini, peneliti juga melakukan pengkatagorian data meliputi: proses promosi pariwisata dan penggunaan Instagram itu sendiri.

Selanjutnya untuk mengecek validitas data, yang peneliti lakukan ialah melakukan observasi terdahulu terhadap akun @ wisatagrobogan kemudian melakukan wawancara dengan tujuan sebagai pelengkap informasi yang berasal dari observasi. Kemudian datayang telah didapatkantersebut dikonfirmasi, dideskripsikan, dikategorikan mana pandangan yang sama, yang berbeda dan mana yang spesifik dari sumber-sumber data tersebut. Terakhir, data dianalisis peneliti hingga menghasilkan kesimpulan. Teknik analisis yang digunakan peneliti tersebut adalah teknik analisis triangulasi sumber.

\section{HASIL DAN PEMBAHASAN}

Adanya pemanfaatan media sosial Instagram sebagai sarana oleh komunitas wisata Grobogan dalam mempromosikan potensi pariwisata daerah, maka peneliti akan mendeskripsikan dan mengelompokan hasil observasi dan wawancarayang telah dilakukan menjadi beberapa kategori, sebagai berikut:

\section{Komunikator}

Preece (dalam Wang, Yu, \& Fesenmaier, 2002) menyatakan bahwa di dalam komunitas daring keberadaan anggota merupakan aset yang paling penting karena komunitas itu terbentuk dengan adanya kesamaan pehamanan maupun kebutuhan disemua anggotanya. Daring disini berarti komunitas ini sosialisasi dan komunikasinya dilakukan tidak dengan bertatap muka secara langsung. Penggambaran komunitas daring tersebut seperti dalam komunitas wisata Grobogan dimana komunitas ini menggunakan media sosial sebagai sarana untuk berpromosi, sosialisai dan berkomunikasi baik dengan pengguna lain maupun dengan anggota komunitasnya sendiri.

Komunitas wisata ini mempunyai visi dan misi. Visi misi komunitas sendiri adalah yang pertama ingin memperkenalkan wisata Grobogan itu saja terlebih dahulu, jadi mereka ingin Grobogan tidak dipandang sebelah mata dan supaya wisata disitu juga bisa ramai seperti daerah-daerah yang lain. Dari penjelasan visi misi oleh informan tersebut lah yang membuat orang lain tertarik untuk mau ikut bergabung dan berpartisipasi langsung mempromosikan potensi pariwisata daerah Grobogan. Salah satu anggota aktif komunitas yaitu Eko, dia mau bergabung dalam komunitas wisata Grobogan. Eko mengatakan:

"Alasannya sederhana mbak, karena saya ini juga pecinta alam secara sukarela"(wawancara dengan Eko, tanggal 31 Juni 2016).

Kegiatan komunitas daring ini tidak dapat terlepas dari penggunaan media sosial dalam bertukar dan saling membagikan informasi mengenai potensi pariwisata daerah Grobogan dengan pengguna lain. Untuk dapat terlaksana dan tercapai tujuan komunitas, maka diperlukan koordinasi dan komunikasi yang baik bagi pengguna lain maupun untuk anggota komunitas sendiri. Penggunaan media sosial sendiri menurut infoman dapat mempermudah mereka dalam berkomunikasi langsung walau tanpa 
tatap muka secara langsung. Selain itu untuk berkomunikasi dengan paraanggotanya pun juga sebagian besar dilakukan melalui media sosial. Media sosial disini seperti Instagram memang dapat digunakan untuk interaksi dua arah secara langsung (Fatanti \& Suyadnya, 2015).

Informan juga menjelaskan mereka juga membuat grup khusus untuk para anggotanya dalam berdiskusi mengenai kegiatan promosi yang akan dilakukan. Penggunaan grup tersebut dirasa sangat efektif dan maksimal dalam berkomunikasi antara satu anggota dengan yang lain. Namun ada salah satu informan yang mempunyai perbedaan pendapat, seperti lyan yang mengatakan:

" saya juga ada grup, kalau grup menurut saya juga nggak maksimal. Saya mending kalau menghubungi itu one by one. Seumpama telepon juga saya langsung telepon jadi kayak gitu. Jadi saya nggakseneng grup itu kan kadang bisa bikin pro krontra bisa bikin masalah"(wawancara dengan lyan, tanggal $25 \mathrm{Mei}$ 2016)

Selain itu, beberapa anggota komunitas wisata Grobogan mempunyai kemampuan fotografi. Agar pesan dalam foto yang digunakan untuk mempromosikan potensi pariwisata daerah selaras dan berimbang serta sesuai dengan tujuan komunitas maka ditunjuklah seorang admin akun @wisatagrobogan. Adminlah yang bertanggung jawab untuk memilih mana yang akan diunggah dan mana yang tidak. Hal tersebut menurut informan dilakukan agar bisa menarik perhatian pengguna lain. Jadi memang harus ada trik-trik tertentu yang digunakan, dengan apa yang mereka unggah agar followernya cepat menjadi banyak dan bagaimana orang mau juga berkomentar dalam foto yang di unggah. Seperti yang dikatakan lyan selaku admin dan juga pendiri komunitas yang mengatakan:

"bagaimana orang itu bisa biar tertarik dengan yang kita unggah gimana kadang saya bikin sesuatu yang kontroversial. Ketika gambar kita upload kita bikin editannya terlalu. lya ada kan, sebenernya cuma trik saja biar orang tertarik komen di situ" - (wawancara dengan lyan, tanggal 25 Mei 2016).

Dari keterangan informan tersebut sejalan seperti yang dikatakan oleh Bakhsi dalam (Hiram, Winnie, Ernest, \& Sally, 2015), menjelaskan bahwa penggunaan gambar lebih menarik dan efektif untuk menjalin komunikasi yang lebih luas dibandingkan dengan penggunaan kata-kata. Di dalam Instagram sendiri memang merupakan media sosial yang telah unggul dalam hal deskripsi visual berupa gambar dibandingkan dengan sosial media yang lain. Informan juga menjelaskan dalam menyeleksi foto mereka juga tidak harus bertemu, bisa langsung dikirim secara daring.

Adanya pernyataan tersebut menunjukan bahwa dengan media sosial mereka dapat menggunakannya dalam mengembangkan ide, mengumpulkan bahan, bertukar informasi dan membujuk pengguna lain untuk mau ikut terlibat dan berpartisipasi dengan komunitas wisata Grobogan.

\section{Pesan}

Melihat dari hasil observasi dan wawancara dalam penggunaan Instagram juga memainkan peran penting sebagai sumber informasi yang dipercaya oleh banyak orang. Jaringan internet banyak digunakan oleh wisatawan untuk memperoleh informasi mengenai wisata, menjalin hubungan, berbagi pengalaman dan juga bisa berbagi tujuan ataupun semua produk yang berhubungan dengan pariwisata (Sciences, 2008). Seperti pemanfaatan media sosial berbasis internet yang dilakukan komunitas wisata Grobogan. Dari hasil observasi dan wawancara maka dalam pengkatagorian pesan dibagi lagi menjadi 2 bagian, antara lain:

1. Foto

Dengan adanya fotografi digital memungkinkan wisatawan selain bisa menyimpan sebagai referensi visual, mereka juga bisa berbagi didalam media sosial dan dapat mewujudkan representasi sosial tertentu dalam sebuah gambar yang disebarkan hingga bisa juga memunculkan 
umpan balik. Kekuatan foto sendiri juga bisa digunakan sebagai mediator teknologi dalam penciptaan dan difusi citra tujuan wisata (Martínez et al., 2014).Seperti yang dilakukan oleh komunitas wisata Grobogan, dimana dalam penggunaan Instagram @ wisatagrobogan biasanya pesan yang disampaikan komunitas salah satunya dengan menggunakan foto. Agar pesan dengan melalui foto ini dapat menarik perhatian para pengguna Instagram lain lyan mengatakan :

"Misalnya kalau dari gambar-gambar itu kan dari gambar kadang kan kondisi di lingkungan misalnya kotor gitu ya, itu langsung tak ambil gambarnya gimana reaksi mereka. Kadang kan banyak juga dari temen-temen melihat tak posting foto kotor itu mereka mengajak "ayo kita kapan bersih-bersih?" -(wawancara dengan lyan, tanggal 25 Mei 2016).

Jadi dari wawancara dengan lyan di atas menyebutkan bahwa dengan foto keadaan asli ditempat wisata dapat memunculkan pesan tersendiri untuk dapat menarik perhatian pengguna Instagram lain. Adanya penggunaan foto yang dilakukan komunitas tersebut merupakan bentuk praktek baru dalam kegiatan M-tourism (pariwisata mobile) (Martínez et al., 2014).

Foto-foto yang diunggah menurut informan juga harus memiliki kriteria tertentu agar pengguna lain tertarik. Untuk memperoleh kriteria foto yang diinginkan maka harus ada penyeleksian terhadap foto-foto yang didapat. Seleksi foto tersebut seperti: memilih foto-foto yang bagus, tempat yang belum terekspos media, foto yang diambil dari sudut yang berbeda walau masih dalam satu tempat wisata dan tentunya pada wisata-wisata yang baru yang belum dikenal masyarakat luas. Kegiatan seleksi foto ini menurut informan dilakukan oleh admin, namun disisi lain anggota yang lain juga bisa menyarankan foto yang mana yang bisa diusulkan kepada admin agar bisa diunggah.

Foto-foto yang diunggah dalam @ wisatagrobogan sendiri dari hasil observasi menunjukan bahwa dalam setiap harinya untuk jumlah unggahannya tidak menentu, bisa dua, tiga bahkan lebih. Yang pasti setiap harinya @wisatagrobogan selalu mengunggah foto minimal satu. Hal tersebut dikarenakan kebanyakan orang cenderung mendukung dalam penggunaan gambar untuk mendapatkan fenomena yang bisa langsung disajikan dalam media jejaring daring dan dalam kehidupan nyata (Ara et al., 2014).

Dimana telah disimpulkan bahwa $76,1 \%$ orang-orang memposting fotofoto perjalanan mereka menggunakan media sosisal seperti Instagram. Selain itu dalam penggunaan foto dalam Instagram mencapai 1.265 .080 foto yang diposting pengguna(Ara et al., 2014). Serta didukung dengan Syed-Ahmad, Tussyadian dan Fesenmi dier (dalam Martínez, Berrozpe, \& Lasarte, 2014) yang juga menunjukan bahwa faktanya, kebanyakan wisatawan memang lebih percaya gambar dan opini wisatawan lain dibandingkan dengan apa yang telah disajikan perusahaan yang jelas ada pada bidang wisata lainnya. Opini wisatawan lain disini dari hasil observasi yang dilakukan peneliti pada akun @wisatagrobogan juga tercantum dalam bentuk komentar-komentar para wisatawan atau para pengguna lain yang ada pada setiap foto yang diunggah admin pada Instagramnya tersebut.

Sehingga foto disini memang diutamakan oleh komunitas wisata Grobogan untuk dapat dengan mudah menarik perhatian pengguna lain dan dirasa efektif untuk menunjukan keaadaan asli pada tempat wisata yang diubah dalam bentuk visual.

\section{Caption}

Sebagian besar dalam mengunggah foto, komunitas wisata Grobogan juga menyertakan caption pada setiap foto-foto unggahannya. Hasan (2015) mengatakan bahwa promosi merupakan kegiatan pemasaran yang tujuannya untuk menarik perhatian wisatawan potensial ke destinasi wisata tertentu dan menikmati berbagai kegiatan yang di rancang dalam pariwista. Disebutkan juga bahwa dalam berpromosi juga mempunyai cara berbeda-beda, tergantung dimana akan berpromosi, daring 
atau offline atau kombinasi keduanya.

Dalam mempromosikan potensi pariwisata daerah, Yayang menyatakan bahwa bukan hanya foto saja yang digunakan untuk menarik perhatian pengguna Instagramlain, melainkan juga didalam foto tersebut juga ada ajakan untuk ke tempat wisata serta ajakan agar pengguna lain mau bergabung dalam komunitas dan ikut berpartisipasi langsung dalam komunitas. Salah satu captionnya yaitu:

"Mari bergabung dengan wisata Grobogan dan menjadi bagian dalam aksinya"- (caption pada foto unggahan tanggal 18 Januari 2016)

Bukan hanya itu saja penggunaan caption yang dilakukan. Eko berkata:

"Biasanya kalau di foto gitu selalu diberi keterangan lengkap mbak, jadi orang lebih mudah untuk mau pergi ke tempatnya"- (wawancara dengan informan 4, tanggal 30 Mei 2016).

Jadi dari hasil wawancara yang dinyatakan Eko menunjukan bahwa caption di sini juga berisikan mengenai informasi lengkap mengenai lokasi tempat wisatanya. Dari observasi yang dilakukan peneliti juga menjunjukan adanya caption yang menginformasikan keterangan lokasi lengkap foto, seperti salah satu contohnya yaitu:

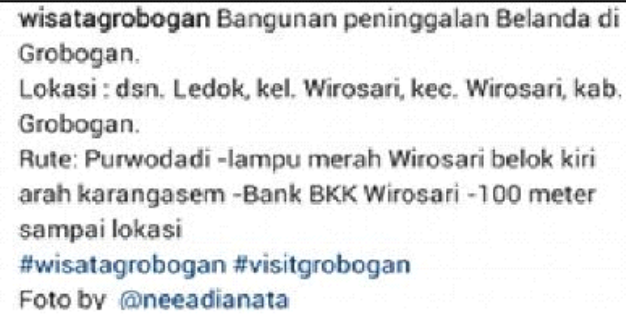

Gambar1.1 (caption pada foto unggahan tanggal 29 Desember 2015)

Caption foto disini menurut informan digunakan bukan hanya untuk itu saja. Caption foto juga dibuat terkadang untuk menyatakan ucapan selamat kepada pengguna lain yang fotonya direpost dan juga untuk keterangan lengkap yang digunakan saat komunitas wisata Grobogan dalam menyebarkan informasi saat akan membuat berbagai acara, lomba maupun kopdar.

\section{Saluran}

Komunitas wisata Grobogan disini menggunakan Instagram sebagai saluran untuk mempromosikan potensi pariwisata daerah. Instagrammenurut informan merupakan media sosial yang saat ini lagi tren, booming dan banyak yang menggunakan. Memang Instagramadalahaplikasiyang paling populer yang menggabungkan smartphone dengan kamera dan kemungkinan dapatakses konstan ke media sosial yang memungkinkan mudah untuk berbagi gambar dari kehidupan masyarakat (Ara et al., 2014). Seperti yang telah disebutkan Abbott et al (dalam Hiram et al., 2015) dimana pada tahun 2013 Instgram digunakan oleh 100 juta orang dan foto yang diunggah berjumlah kurang lebih 4 miliar. Selain itu pada 2014 Smith (dalam Hiram et al., 2015) juga menunjukan data dimana adanya kenaikan pengguna Instagram berjumlah 75 juta orang tiap harinya. dan jumlah foto yang diunggah juga meningkat menjadi 16 miliar. $\mathrm{Hal}$ tersebut menunjukan bahwa Instagram semakin diminati oleh banyak orang.

Selain itu seperti yang ditunjukan oleh lyan dimana ia juga telah membuktikan sebelumnya dahulu sudah punya akun Instagram tapi peminatnya sedikit, sedangkan sekarang ia memasang Instagram lagi dan membuat akun lagi di Instagram yaitu@ wisatagrobogan peminatnya banyak serta mendapatkan respon cepat dari pengguna lain. Sebenarnya banyak media sosial yang mereka pakai, tetapi Yayang mengatakan:

"Tapi menurutku malah efektif di Instagram. Instagram efektif, fanspage juga. Tapi tak lihat juga banyak, kok tau acara ini dari mana pasti kebanyakan dari Instagram gitu.Followernya banyak"(wawancara dengan Yayang, 31 Mei 2016).

Memang menurut informan lainnya juga menyatakan bahwa Instagram dianggap media yang paling efektif yang digunakan oleh komunitas wisata Grobogan ini. Sama seperti menurut Abbott (dalam (Hiram et al., 2015), yang menyatakan bahwa Instagram merupakan media yang efektif untuk 
meningkatkan peluang bisnis maupun untuk eksistensi diri dengan menciptakan identitas. Instagram mempunyai kelebihan seperti mempunyai fitur-fitur seperti:

\section{Sharing}

Sharing disini ialah komunitas berbagi foto potensi pariwisata Grobogan dengan memanfaatkan hashtag tujuannya agar potensi pariwisata daerah Grobogan banyak yang mengetahuinya. Seperti yang dikatakan oleh Eko:

"kemungkinan Instagram itu kan popular sebagai salah satu tempat sharing hasil foto mbak"- (wawancara dengan Eko, 30 Mei 2016)

Dari pernyataan Eko menunjukan hal yang sama seperti yang dinyatakan oleh Frommer (dalam Sheldon \& Bryant, 2016), dimana Instagram merupakan media daring yang lebih berfokus pada konteks foto dan video, sehingga memungkinkan pengguna Instagram bisa menyebar atau mengambil foto maupun video yang telah di unggahnya sendiri maupun yang telah diunggah pengguna lain.

Selain itu didalam unggahan foto tersebut dari hasil observasi yang dilakukan juga terdapat komentar yang isinya dimana @wisatagrobogan saling berbagi informasi dengan pengguna Instagram lain. Seperti contoh berbagi informasi mengenai potensi pariwisata baru, informasi mengenai letak lokasi wisata danmengenai informasi kegiatan offline yang diadakan komunitas. Hal tersebut menunjukan penggunaan media ini bisa untuk berinteraksi dengan orang lain (Hiram et al., 2015).

Sehingga sharing disini dilakukan dengan tujuan untuk saling berbagi informasi antara satu dengan yang lain. Dan komunitas wisata Grobogan disini mencoba menyediakan informasi dengan melalui sharing terhadap pengguna lain yang berguna sebagai referensi mereka sebelum melakukan perjalanan wisata.

2. Hashtag (\#)

Hashtag di sini juga sering digunakan. Dari hasil observasi dan wawancara infoman menyebutkan bahwa \#wisatagrobogan lah yang sering digunakan. Selain itu, hashtaghashtag lain seperti \#dolanpurwodadi \#exploreindonesia \#wonderfullindonesia \#instapic \#jatengeksis \#indonesia dsb juga sering dicantumkan pada setiap mengunggah foto dalam @wisatagrobogan.

Tujuan menggunggah foto dengan pemberian hashtag tersebut adalah agar pengguna lain dapat dengan mudah menemukan foto-foto. Sedangkan fungsi hashtag memang sama seperti pernyataan (Sheldon \& Bryant, 2016), dimana fitur hashtag (\#) dalam Instagram ini berfungsi untuk menandai foto-foto yang diunggah pengguna agar pengguna lain saat mencari dengan kata kunci hashtag tersebut dapat dengan mudah menemukan foto yang kita unggah. $\mathrm{Hal}$ tersebut menunjukan bahwa hashtag merupakan fasilitas penting dalam Instagram dimana dapat memfasilitasi pengguna untuk mendukung dalam penyebaran foto ke pengguna Instagram lain. Selain itu fungsi hashtag juga bisa untuk pengelompokan dalam konten wisata, untuk pencarian konten perjalanan, dapat memperluas postingan pariwisata serta dapat juga digunakan untuk mempromosikan produk pariwisata. Fungsifungsi tersebut menunjukan Instagram memberikan kekuatanyang bisa dimanfaatkan sebagai media promosi kontemporer (Fatanti \& Suyadnya, 2015).

\section{Repost}

Mengenai repost foto, biasanya ini juga berkaitan dengan penggunaan \#wisatagrobogan. lyan mengatakan:

"jadi kalau temen-temenpengen di repost harus pakai hashtag itu"- (wawancara dengan lyan, tanggal 25 Mei 2016)

Intidaripenggunaanrepostyang dilakukan menurut informan ialah fungsinya sama yaitu untuk promosi. Jika pengguna Instagram lain menggunakan \#wisatagrobogan berarti hal tersebut menunjukan bahwa pengguna Instagram lain tersebut sudah pernah kesana. Dengan adanya hashtag tersebut keuntungannya orang menjadi lebih banyak mengetahui wisata-wisata yang ada di Grobogan. Dan juga dalam melakukan repost 
foto Eko berkata:

"Itu terkadang dari kita wisata Grobogan belum sempat datang ke lokasi akhirnya untuk mempromosikannya kita ngambilngambil foto dari akun lain yang juga mendukung wisata Grobogan tersebut" -(wawancara dengan Eko, tanggal $30 \mathrm{Mei}$ 2016).

Dari hasil wawancara dengan Eko tersebut menguatkan pendapat dari informan lainnya dimana repost foto bisa juga digunakan untuk menunjukan potensi wisata yang belum pernah dikunjungi atau diketahui komunitas dapat dipromosikan kembali dengan menyebarluaskan kembali melalui akun@wisatagrobogan dengan merepost pengguna lain yang memberikan tag pada @ wisatagrobogan.

Intinya repost disini digunakan untuk menarik perhatian pengguna lain agar mau melakukan tag foto dan memakai \#wisatagrobogan yang akhirnya foto pengguna lain tersebut berkesempatan bisa direpost dalam @wisatagrobogan. Hal tersebut seperti yang dikatakana oleh Fatanti \& Suyadnya (2015) bahwa Instagram memberikan kesempatan untuk tujuan wisata baru berdasarkan pengalaman individu sebelumnya.

\section{Findergram}

Penggunaan Findergram terkait dengan penggunaan hashtag. Di dalam akun @ wisatagrobogan lyan mengatakan:

"Iya memakai, ya kadang ada yang menandai dan kadang saya searching melalui hashtag tersebut. Ada yang masuk nggak"- (wawancara dengan lyan, tanggal 25 Mei 2016)

Sehingga keuntungan dalam menggunakan Findergram menurut informan adalah gampang untuk menemukan foto. Foto disini yang di maksut adalah foto-foto yang memakai hashtag\#wisatagrobogan dan foto tersebut akan berkesempatan untuk dipilih dan di repost ke @wisatagrobogan.

Keuntungan dalam menggunakan Findergram tersebut sama seperti yang telah dijabarkan oleh (Martínez et al., 2014) bahwa melalui Findergram memungkinkan pencarian hashtag, yang juga memberikan pilihan dalam menampilkan gambar yang sedang diunggah mereka secara real-waktu. Namun pencarian hashtag disini lebih terbatas, karena hanya menampilkan foto yang menggunakan hashtag tertentu yang fungsinya juga bisa untuk pengelompokan foto-foto.

\section{WorldCam}

Untuk penggunaan WorldCam sendiri dalam @wisatagrobogan dari hasil observasi sering dicantumkan pencarian umum dengan menggunakan beberapa hashtag seperti \#indonesia \#wonderfullindonesia \#jatengeksis dsb. Menurut semua informan keuntungan menggunakan hashtag umum tersebut dikarenakan hashtag-hashtag tersebut banyak yang menggunakan. Sehingga bisa untuk memperkenalkan Indonesia sendiri dalam cakupan yang lebih luas lagi. Semakin banyak hashtag yang dipakai dapat membuat semakin banyak followernya. Seperti salah satu informan tersebut yang mengatakan:

"kita memakai hashtag-hashtag itu biar lebih dikenal, itu kan kalau memakai berbagai hashtag biasanya terkait dengan akun lain. jadi pengguna akun lain bisa melihat istilahnya gambargambar dari uploadan kita sendiri sama bisa naikin follower"-(wawancara dengan Eko, tanggal 30 Mei 2016).

Pemanfaatan WorldCam tersebut bisa untuk seacrh engine untuk menemukan geolocated foto yang tidak hanya di kota melainkan bisa pada tempat-tempat lain dari berbagai kota (Martínez et al., 2014).Dengan dipakainya worldcam ini maka seluruh orang pengguna Instagram baik yang berasal di dalam Indonesia maupun yang tinggal di luar negeri bisa menemukan unggahan foto yang dilakukan komunitas wisata Grobogan tersebut.

\section{SearchStagram}

Penggunaan SearchStagram pada akun @ wisatagrobogan terlihat dengan adanya akun lain yang direkomendasikan oleh komunitas wisata Grobogan dalam akunnya seperti merekomendasikan akun @visitgrobogan 
dan @persipurpurwodadi. Keuntungan menggunakan SearchStagram sendiri menurut informan hal tersebut istilahnya untuk saling membantu mempromosikan Grobogan, karena mereka sama-sama di Grobogan dan memakai nama Grobogan. Berbeda dengan Uul yang menyatakan penggunaan seacrhstagram sendiri ia belum begitu mengetahuinya.

Ketika pengguna melakukan tag foto tersebut, maka Instagram secara otomatis mengaitkan tag foto tersebut langsung ke akun penggunanya. Bukan hanya itu saja, bila pengguna lain melakukan pencarian melalui tag tersebut maka pengguna lain juga langsung bisa melihat akun yang dikaitkan bahkan bisa membuat pengguna lain mengikuti akun tersebut juga (Landsverk, 2014). Pernyataan lain juga dinyatakan oleh (Martínez et al., 2014), bahwa penggunaan seacrhstagaram memang dapat digunakan dalam pencarian kata kunci dan hashtag serta di dalamnya juga menyarankan atau merekomendasikan hashtag terkait.

Sehingga dengan search stagram ini para pengguna lain bisa dengan mudah saling berkomunikasi dan saling membantu satu sama lain untuk saling berpromosi dan dapat memperkuat upaya mereka dalam mempromosikan produk masing-masing tanpa ada yang dirugikan namun yang ada saling menguntungkan satu sama lain.

\section{Geolocation}

Geolocation digunakan baru-baru ini, dari bulan Oktober 2015 sampai Mei 2016 penggunaan geolocation paling banyak digunakan dari bulan April sampai Mei 2016. Sebelumnya geolocation juga sempat dicantumkan, seperti pada bulan Februari dan Maret 2015, namun penggunaannya hanya dibeberapa foto saja tidak semuanya memakai.

Untuk penggunaan geolocation sendiri pengoperasian dan penggunaannya dilakukan oleh admin yang bertanggung jawab memegang akun Instagram komunitas. Sebenarnya geolocation menurut Fatanti \& Suyadnya (2015) bisa juga disebut sebagai geo-tagging yang mempunyai fasilitas yang sama dalam mempermudah bagi pengguna lain untuk menunjukan lokasi dimana foto itu diambil langsung.

Fitur tersebut memang digunakan untuk menambahkan informasi lokasi foto diambil oleh pengguna. Jika pengaturan map foto diaktifkan maka secara otomatis akan melampirkan lokasi pada foto. Ketika pengguna melampirkan lokasi tersebut maka pengguna lain juga akan bisa melihat dimana anda mengambil foto yang anda unggah tersebut (Landsverk, 2014).

Namun sayangnya penggunaan geolocation pada @wisatagrobogan tidak disetiap foto ada. Penggunaan geolocation yang mencantumkan letak lokasi wisata secara otomatis tidak sering digunakan karena menurut lyan yang sekaligus menjadi admin menyatakan bahwa biasanya pada tempattempat yang baru lokasi sulit ditemukan melalui GPS. Karena juga penggunaan HP yang tidak mendukung.

\section{Komunikan}

Komunikan disini dibagi menjadi 3 bagian untuk di diskripsikan secara rinci, pembagiannya sebagai berikut:

\section{Follower}

Dari hasil observasi pada akun @ wisatagrobogan terlihat jumlah followernya dari awal bulan Oktober, November 2015 yang hanya mencapai 6 ribu follower kini pada bulan Mei 2016 meningkat menjadi 18 ribufollower.

\section{Tabel Kenaikan Follower}

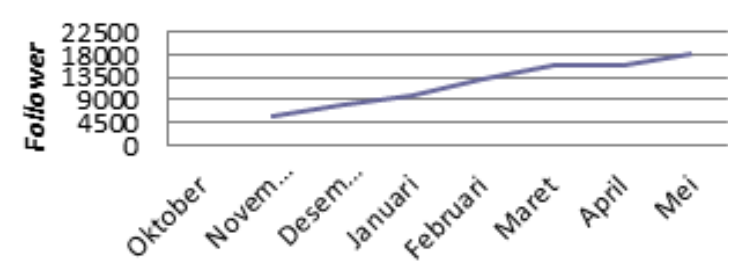

Gambar 1.2 (Tabel kenaikan follower)

Dapat dilihat dalam tabel tersebut menunjukan upaya mempromosikan potensi pariwisata Grobogan melalui Instagram mendapatkan respon dari pengguna. Dari 
situ membuktikan banyak yang tertarik pada akun@wisatagrobogan hingga mereka mau mengikuti aktivitas @wisatagrobogan dan mau menjadi followernya.

Hal tersebut terkait dengan adanya dari awal Instagram diluncurkan pada Oktober 2010 mengalami peningkatan jumlah pengguna dan upload foto. Tercatat bahwa pada 2013 hampir 46.000.000 pengguna aktif setiap bulan, 9 juta setiap hari, menurut App Data (dalam Martínez et al., 2014).Serta banyaknya follower dalam akun komunitas wisata juga menunjukan bahwa ketika seseorang dalam merencanakan perjalanan biasanya mereka cenderung terlebih dahulu melakukan pencarian informasi yang ekstentif terhadap lokasi wisata. Serta banyaknya follower yang didapat juga merupakan salah bukti bahwa komunitas daring memainkan peran penting dalam penyediaan sumber informasi yang dapat dipercaya di pasar global yang dinamis (Sciences, 2008).

Karena yang memegang akun @ wisatagrobogan adalah admin dan hanya satu orang saja, maka yang paling banyak mengetahui lalu lintas dalam @ wisatagrobogan adalah admin. Mengenai follower, lyan berpendapat:

"saya melihat kok dunia maya kan banyak kayak Instagram dll semua tak cobain responnya yang bagus yang mana gitu. Saya bikin Instagram itu cepet banget, jadi satu hari itu lebih dari seratus orang follower itu lebih dari seratus oraang tiap hari. Jadi ini cepet banget pokoknya. Sehari semalam itu kurang lebih seratus orang" ( wawancara dengan informan 1, tanggal 25 Mei 2016).

Selain itu, dalam mempromosikan potensi pariwisata daerah menurut semua informan tidak ada bidikan untuk orangorang tertentu supaya datang berkunjung ke Grobogan. Hanya saja yang paling utama targetnya ialah masyarakat Grobogan itu sendiri mau mencintai wisatanya, pertama itu dulu. Terutama untuk kalangan muda yang biasanya aktif juga dalam menggunakan media sosial.

\section{Repost}

Repost foto menurut informan memang sengaja dilakukan untuk mendapatkan perhatian dari pengguna lain. Repost foto dilakukan agar pengguna lain terpacu untuk mau berpartisipasi supaya mau membagikan fotonya dengan komunitas wisata Grobogan dengan cara mencamtumkan \#wisatagroboan dan meng tag@ @wisatagrobogan. Selain itu informan juga menjelaskan bahwa dalam melakukan repost foto biasanya diseleksi terlebih dahulu dan tidak asal di repost oleh admin. Hal tersebut dikarenakan banyaknya pengguna lain yang berpartisipasi ingin membagikannya di akun @wisatagrobogan. Di lain sisi repost foto juga bermanfaat untuk menambah informasi serta referensi baru terhadap potensi wisata yang belum sempat dikunjungi oleh komunitas. Seperti yang dikatakan oleh Eko mengenai alasan melalukan repost foto yaitu:

"Itu terkadang dari kita wisata Grobogan belum sempat datang ke lokasi akhirnya untuk mempromosikannya kita ngambilngambil foto dari akun lain yang juga mendukung wisata Grobogan tersebut"( wawancara dengan Eko, tanggal $30 \mathrm{Mei}$ 2016).

Dijelaskan sebelumnya bahwa saat ini fotografi dianggap sebagai alat yang sangat ampuh untuk mengungkapkan perasaan dan menceritakan tentang peristiwa kehidupan yang penting untuk sejumlah orang. Biasanya fenomena sekarang initerlihatfoto memainkan peran penting dalam mengabdikan moment tertentu, bisa dari pengalaman perjalanan wisata ke objek wisata tertentu dan lain-lain.

Dengan repost foto ini menurut (Ara et al., 2014) memungkinkan kita untuk megidentifikasikan praktik pengguna dan akibatnya, kumungkinan hal tersebut masuk tren baru mengenai bagaimana orang berinteraksi dan berbagi fotografi di era baru dari jaringan media sosial.

3. Feedback

Mengenai Feedback antara komunitas dengan para pengguna Instagram lain dapat dilihat pada akun @wisatagrobogan dimana banyak terdapat pengguna lain 
yang berkomunikasi dengan admin wisata Grobogan melalui komentar-komentar pada setiap foto yang diunggah @wisatagrobogan. Banyak komentar yang menunjukan mereka bangga terhadap potensi wisata yang telah diunggah oleh admin di @wisatagrobogan. Hal tersebut menunjukan bahwa dalam Instagram juga bisa memungkinkan komunikasi dua arah dapat berlangsung (Fatanti \& Suyadnya, 2015).

Selain itu pada akun @wisatagrobogan juga mencantumkan atau menyediakan media sosial lain bagi para pengguna Instagram lain yang ingin berkomunikasi menanyakan seputar wisata Grobogan. Untuk lebih jelasnya bisa juga menggunakan BBM, Line, WA dan juga di sediakan nomor admin. lyan juga menambahkan bahwa:

"ada juga yang dari luar negeri ada yang sering komen ada juga yang sering BBM an dari Malaysia juga sering tanya-tanya. Jadi bisa memperkenalkan Indonesia sendiri lebih luas lagi"- (wawancara dengan informan 1, tanggal 25 Mei 2016)

Pernyataan Iyan tersebut terlihat bahwa follower dari @wisatagrobogan sendiri berisikan bukan hanya masyarakat Grobogan melainkan masyarakat luar Indonesia pun juga menjadi salah satu followernya. Adanya pernyataan tersebut juga menunjukan dimana semua media sosial yang berbasis internet memungkinkan antara satu orang dengan ratusan orang bahkan ribuan orang bisa berkomunikasi (Martínez et al., 2014)

\section{E. PENUTUP}

Komunikasi pariwisata yang dilakukan oleh komunitas wisata Grobogan yaitu dengan dengan cara menyebarkan informasi potensi wisata melalui Instagram. Media sosial tersebut dipilih karena mempunyai banyak kelebihan dan banyak memberikan keuntungan. Komunikasi pariwisata oleh komunitas wisata Grobogan dilakukan melalui empat tahapan dengan adanya komunikator yang di tunjuk sebagai penyebar informasi serta yang bertanggung jawab pada@wisatagrobogan, adanya pesan berupa informasi wisata yang disampaikan dalam bentuk foto dan captionsebagai pelengkap informasi foto, adanya saluran yaitu Instagram yang dipilih sebagai media penyebar informasi wisata dan adanya komunikan dimana komunikan disini yang paling utama adalah masyarakat Grobogan yang menjadi target sasaran komunitas. Selain itu komunitas wisata Grobogan lebih memilih Instagram dikarenakan dibanding dengan media konvensional, Instagram dalam upaya mempromosikan pariwisata daerah lebih banyak mempunyai fitur yang dapat dimanfaatkan. Fitur-fitur dalam Instagram berupasharing, hashtag, repost, findergram, worldcam, seacrhstagram, dan geolocation. Dari beberapa fitur-fitur tersebut yang paling utama dan yang paling bisa digunakan untuk menarik pengguna lain yaitu dengan sharing foto dan repost foto, sedangkan fitur-fitur yang lain digunakan sebagai pendukung tambahan dalam mempromosikan potensi pariwisata daerah.

\section{F. PERSANTUNAN}

Peneliti ingin mengucapkan terimakasih kepada banyak pihak yang telah membantu dalam menyelesaikan penelitian ini. Diantaranya kepada:

1. Ibu Palupi, MA selaku pembimbing skripsi.

2. Keempat informan peneliti yang sudah membantu penelitian ini.

\section{DAFTAR PUSTAKA}

\section{Referensi dari Jurnal:}

Ara, C. S., Paulo, L., Corr^, D., Paula, A., Prates, R. O., \& Jr, W. M. (2014). It is not just a picture : Revealing some user practices in Instagram, (May). 
Ardella, A. M. P. (2015). Pemanfaatan Media Sosial Oleh Senyum Community Sebagai Persuasi Cyber Social Enterprise. Journal UMS.

Ballantine, P., \& Ballantine, P. W. (2016). Forming Parasocial Relationships in Online Communities Forming Parasocial Relationships in Online Communities, (April).

Bash, E. (2015). Making Strategis in Destination Branding: What is the online tourism promotional material saying abaut Portugal? PhD Proposal, 1(March 2013), 1-8. http:// doi.org/10.1017/CBO9781107415324.004

Cangara, H. (2006). Pengantar Ilmu Komunikasi. Jakarta: Raja Grafindo Persada.

Djamarah, S. B. (2004). Pola Komunikasi Orang Tua dan Anak dalam Keluarga. Jakarta: Rineka Cipta.

Fatanti, M. N., \& Suyadnya, I. W. (2015). Beyond User Gaze: How Instagram Creates Tourism Destination Brand? Procedia - Social and Behavioral Sciences, 211, 1089-1095. http:// doi.org/10.1016/j.sbspro.2015.11.145

Gohil, N. (2015). Role and Impact of Social Media in Tourism : A Case Study on the Initiatives of Madhya Pradesh State Tourism INTRODUCTION : REVIEW OF LITERATURE :, 5(4), 8-15.

Hasan, A. (2015). Tourism Marketing. Yogyakarta: CAPS (Center For Academic Publishing Service).

Herdiansyah, H. (2013). Wawancara, Observasi dan Focus Group: Sebagai Instrumen Penggalian Data Kualitatif. Jakarta: Rajawali Pers.

Hiram, T., Winnie, W. P. M., Ernest, C. de R., \& Sally, L. Y. C. (2015). Beliefs about the Use of Instagram : An Exploratory Study, (January).

Ismayanti. (2011). Pengantar Pariwisata. Jakarta: Grasindo.

Karyati, T., Mulyani, S., Rachmat, Junarti, \& Sunarto. (2007). Pendidikan Lingkungan Budaya Jakarta. Jakarta: Ganeca Exacf.

Komputindo, E.-M. (2008). Membangun Komunitas Online Praktisgratis. Jakarta: Elex Media Komputindo.

Kume, T. (2015). The Effect of Father Involvement in Childcare on the Psychological Wellbeing of Adolescents: A Cross-Cultural Study. ISSN 1839-7816 VOL. 4, ISSUE 1, 38 51.

Landsverk, K. H. (2014). The Instagram Handbook. London: PrimeHead Limited.

Liu, B. (2016). A Flash of Culinary Tourism : Understanding The Influences of Online Food Photography on People's Travel Planning Process on Flickr, (January 2013).

M. Liga Suryadana, V. O. (2015). Pengantar Pemasaran Pariwisata. Bandung: Alfabeta.

Mardalis. (2006). METODE PENELITIAN: Suatu Pendekatan Proposal. Jakarta: PT Bumi Aksara.

Martínez, M. P. L., Berrozpe, T. I., \& Lasarte, M. P. (2014). Image-focused social media for a market analysis of tourism consumption. International Journal of Technology Management, 64(1), 17. http://doi.org/10.1504/IJTM.2014.059234

Oktavia, M. L. (2015). Pengantar Pemasaran Pariwisata. Bandung: Alfabeta. Sciences, T. (2008). Web 2 . 0 : A study of online travel community, 70-81. Retrieved from http:// dblp.uni-trier.de/db/conf/enter/enter2008.html\#ChungB08

Sheldon, P., \& Bryant, K. (2016). Instagram: Motives for its use and relationship to narcissism and contextual age. Computers in Human Behavior, 58(May), 89-97. http://doi. 
org/10.1016/j.chb.2015.12.059

Utama, I. G. (2014). Pengantar Industri Pariwisata: Tantangan \& Peluang Bisnis Kreatif. Yogyakarta: Deepublish.

Wang, Y., Yu, Q., \& Fesenmaier, D. R. (2002). Defining the virtual tourist community: Implications for tourism marketing. Tourism Management, 23(4), 407-417. http://doi. org/10.1016/S0261-5177(01)00093-0 